\title{
Comparative evaluation of published real-time PCR assays for the detection of malaria following MIQE guidelines
}

Saba Alemayehu, Karla C Feghali, Jessica Cowden, Jack Komisar, Christian F Ockenhouse and Edwin Kamau*

\begin{abstract}
Background: The use of malaria-specific quantitative real-time PCR (qPCR) is increasing due to its high sensitivity, speciation and quantification of malaria parasites. However, due to the lack of consensus or standardized methods in performing $\mathrm{QPCR}$, it is difficult to evaluate and/or compare the quality of work reported by different authors for a cross-study and/or cross-platform assay analysis.
\end{abstract}

Methods: The performances of seven published qPCR assays that detect Plasmodium spp or Plasmodium falciparum were compared using standard DNA and samples from a clinical trial. Amplification and QPCR measurements were performed using the Applied Biosystems 7500 Fast Real-Time PCR System. All the analyses were automatically established using the default settings. For the TaqMan probe format, the assays were performed in the background of QuantiFast Probe Master Mix whereas in SYBR Green format, the assays were performed in the background of QuantiFast SYBR Green Master Mix and QuantiTect SYBR Green Master Mix background.

Results: Assays with high PCR efficiencies outperformed those with low efficiencies in all categories including sensitivity, precision and consistency regardless of the assay format and background. With the exception of one assay, all assays evaluated showed lower sensitivity compared to what have been published. When samples from a malaria challenge study were analysed, the GPCR assay with the overall best performance detected parasites in subjects earliest and with most consistency.

Conclusion: The data demonstrate the need for increased consensus and guidelines that will encourage better experimental practices, allowing more consistent and unambiguous interpretation of GPCR results.

\section{Background}

The gold standard method for malaria diagnosis is microscopy $[1,2]$. However, numerous challenges associated with performing quality microscopy may lead to variations in assay sensitivity and specificity $[3,4]$ affecting patient diagnostic outcome and/or clinical trial results [5]. Microscopy is highly operator-dependent and proficiency testing is required to achieve reproducible, high-quality data [6]. Molecular assays that detect Plasmodium-specific nucleic acid sequences are increasingly being implemented in order to overcome some of the limitations associated

\footnotetext{
* Correspondence: edwin.kamau@us.army.mil

Military Malaria Research Program, Malaria Vaccine Branch, Walter Reed Army Institute of Research, 503 Robert Grant Ave, Silver Spring, MD, USA
}

with microscopy. These assays are several orders of magnitude more sensitive than microscopy or antigen detection tests $[7,8]$. Malaria-specific applications of quantitative realtime PCR (qPCR) have allowed for identification, speciation and quantification of malaria parasites [7-14]. Notably, qPCR is increasingly being used to analyse pre-patent parasitaemia in controlled human malaria infection (CHMI) trials as well as evaluation of low parasitaemia in field studies [15-19]. PCR can also be used as a tool for identification of asymptomatic carriers [20].

Most of the GPCR assays that have been described for detection of Plasmodium target the multicopy $18 \mathrm{~S}$ ribosomal RNA (rRNA) genes [21]. Other targets such 
as mitochondrial genes, var and stevor genes have also been described [13,21]. These assays are designed as monoplex where they amplify a single target or as multiplex, where they amplify two targets or more. When used as a monoplex assay, the reported detection limit ranges from about 0.002 to 30 parasites/ $\mu \mathrm{L}[14,21]$ whereas as a multiplex, the detection limit ranges from 0.2 to 5 parasites $/ \mu \mathrm{L}[7,8,14,21]$. Hermsen et al. [9] and Lee et al. [10] described some of the early monoplex qPCR assays for detection of Plasmodium spp with a detection limit of 0.02 parasites $/ \mu \mathrm{L}$ and 0.1 parasites $/ \mu \mathrm{L}$ respectively. Both of these studies targeted the rRNA genes. Recently, Farrugia et al. [13] described a monoplex assay that targets cytochrome $b$ gene $(c t y b)$ with a detection limit of 0.05 parasites $/ \mu \mathrm{L}$. Although these and other studies follow similar study methods, differences in space and time, reagents, standards used for quantification, dilution ranges, instruments or platforms, assay analysis methods, data interpretations, and much more, contribute to differences in the reported detection limits. Due to lack of consensus or standardized methods in performing qPCR, it is difficult to evaluate and/or compare the quality of work reported by different authors for a cross-study and/or cross-platform assay analysis. This also impedes the ability to reproduce reported assays.

The minimum information for publication of quantitative real-time PCR experiments (MIQE) guidelines were published recently [22]. They address the reliability of qPCR results to help ensure the integrity of the scientific literature, promote consistency between laboratories, and increase experimental transparency. The use of malaria qPCR as a confirmatory clinical endpoint assay in field research is increasing exponentially as reflected in the large number of publications reporting GPCR data. In addition, there have been discussions of molecular assays replacing microscopy as the preferred diagnostic tool for malaria, especially in reference laboratories and in CHMI trials. The lack of consensus on how to best perform qPCR has led to serious difficulty in establishing PCR as an independent yardstick [22] and currently, there is not an FDA approved qPCR assay for detection of malaria. Use of MIQE and other guidelines set-forth will ensure qPCR relevance, accuracy, correct interpretation, reliability, and reproducibility. Towards this effort, it is important to obtain harmonized data from some of currently widely used malaria qPCR assays as an important step towards assay standardization.

In this study, the performance of several published qPCR assays using the WHO international standard for Plasmodium falciparum DNA nucleic acid amplification technology assay as a calibration reference reagent were compared. The experimental conditions, assay analysis methods and data interpretation were uniformly performed for all qPCR assays assessed.

\section{Methods}

Plasmodium falciparum reference reagent

The WHO International Standard for Plasmodium falciparum DNA was used to analyse the efficiency, sensitivity and specificity of published assay targets for Plasmodium spp. and P. falciparum. The reference reagent was obtained from the National Institute for Biological Standards and Control (NIBSC; Hertfordshire, UK). This standard consists of a freeze-dried preparation of whole blood collected from a patient infected with $P$. falciparum by exchange transfusion. Following NIBSC recommendations, the lyophilized material was suspended in $500 \mu \mathrm{L}$ of sterile, nuclease free water to a final concentration of $1 \times$ $10,993 \mathrm{IU} / \mathrm{mL}$, which corresponds to a parasitaemia of 9.79 parasites/100 red blood cells (RBCs) [13]. The parasite density of the WHO International Standard for $P$. falciparum DNA after the reconstitution was estimated to be 469,920 parasites $/ \mu \mathrm{L}$, based on the average $\mathrm{RBC}$ count of $4.8 \times 106 \mathrm{RBC} / \mu \mathrm{L}$. Unless otherwise indicated, fresh uninfected whole blood was used as a diluent to prepare serial dilutions. DNA was extracted using EZ1 automated purification system (Qiagen, CA, USA) using the EZ1 DNA blood kit (Qiagen, CA, USA) following the manufacturer's recommendation. For the purposes of establishing the limit of detection (LoD), DNA was serially diluted five-fold for the first four dilution points followed by two-fold dilutions over five-log range. The lowest concentration of DNA that tested positive in all the replicates was set as the LoD.

\section{Primers and probes}

Seven sets of primers and probes for the detection of Plasmodium spp. and P. falciparum were selected from published work. Table 1 shows the primers and probes sequences selected for this project as published. They were obtained either from Life Technologies (Carlsbad, CA, USA) or Integrated DNA Technologies (IDT-DNA, Coralville, IA, USA). For purposes of simplicity and uniformity, all probes for all the assays were labelled with 6-carboxy-fluorescein (FAM) as a reporter and 6carboxy-tetramethylrhodamine (TAMRA) as a quencher.

\section{qPCR assays and experimental design}

Amplification and qPCR measurements were performed using the Applied Biosystems 7500 Fast Real-Time PCR System, with version 2.0.6 software. All the analyses, including setting of the threshold and the quantification cycle $\left(\mathrm{C}_{\mathrm{q}}\right)$ values, were automatically established using the default settings. Experiments were performed in 96well plates. For the TaqMan probe format, the assays were performed in the background of QuantiFast Probe 
Table 1 Published primers and probes used in analysis

\begin{tabular}{|c|c|c|}
\hline $\begin{array}{l}\text { Assay } \\
\text { name }\end{array}$ & $\begin{array}{l}\text { Primer and Probe sets as published } \\
\text { in } 5-3 \text { orientation }\end{array}$ & Ref \\
\hline \multirow[t]{3}{*}{ PLU3 } & F: GCTCTITCTTGATTTCTTGGATG & [14] \\
\hline & R: AGCAGGTTAAGATCTCGTTCG & \\
\hline & P: ATGGCCGTTITAGTTCGTG & \\
\hline \multirow[t]{3}{*}{ MACH } & F: ACATGGCTATGACGGGTAACG & {$[10$} \\
\hline & R: TGCCTTCCTTAGATGTGGTAGCTA & \\
\hline & P: TCAGGCTCCCTCTCCGGAATCGA & \\
\hline \multirow[t]{3}{*}{ СYTB } & F: TACTAACTTGTTATCCTCTATTCCAGTAGC & [13] \\
\hline & R: CCTTTAACATCAAGACTTAATAGATTTGGA & \\
\hline & $\mathbf{P}: \mathrm{G}+\mathrm{TGC}+\mathrm{TAC}+\mathrm{CAT}+\mathrm{GTA}+\mathrm{AAT}+\mathrm{GTAA}$ & \\
\hline \multirow[t]{3}{*}{ WHO } & F: CAGATGTCAGAGGTCAAATTCTAAGATT & {$[12$} \\
\hline & R: TCCCTTAACTTTCGTTCTTGATTAATG & \\
\hline & P: CTGGAGACGGACTACTGCGAAAGCATTTG & \\
\hline \multirow[t]{3}{*}{ FAL } & F: CTTTGAGAGGTTTGTTACTTGAGTAA & [7] \\
\hline & R: TATTCCATGCTGTAGTATTCAAACACAA & \\
\hline & P: TGTTCATAACAGACGGGTAGTCATGATTGAGTTCA & \\
\hline \multirow[t]{3}{*}{ PLASMO } & F: GTTAAGGGAGTGAAGACGATCAGA & {$[11$} \\
\hline & R: AACCCAAAGACTTTGATTTCTCATAA & \\
\hline & P: ACCGTCGTAATCTTAACCATAAACTATGCCGACTAG & \\
\hline \multirow[t]{3}{*}{ TURBO } & F: GTAATTGGAATGATAGGAATTTACAAGGT & [9] \\
\hline & R: TCAACTACGAACGTTTTAACTGCAAC & \\
\hline & P: TGCCAGCAGCCGCGGTAATTC & \\
\hline
\end{tabular}

Primers and probes sequences as published. Forward and reverse primers are shown as $F$ and R. All probes shown as $P$ were labelled with 6-carboxy -fluorescein (FAM) as a reporter and 6-carboxy-tetramethylrhodamine (TAMRA) as a quencher to maintain uniformity. The last column shows the reference where primers and probe for each assay were obtained.

Master Mix whereas in SYBR Green format, the assays were performed in the background of QuantiFast SYBR Green Master Mix and QuantiTect SYBR Green Master Mix background (Qiagen, CA, USA). The following thermal profiles described below are for each master mixes used:

\section{QuantiFast Probe TaqMan:}

Stage 1(Holding Stage): $95^{\circ} \mathrm{C}$ for $5 \mathrm{~min}$

Stage 2 (Cycling Stage): $95^{\circ} \mathrm{C}$ for $10 \mathrm{sec}, 60^{\circ} \mathrm{C}$ for $30 \mathrm{sec}$ \} 45 Cycles

\section{QuantiFast SYBR Green:}

Stage 1 (Holding Stage): $95^{\circ} \mathrm{C}$ for $5 \mathrm{~min}$ Stage 2 (Cycling Stage): $95^{\circ} \mathrm{C}$ for $10 \mathrm{sec}, 60^{\circ} \mathrm{C}$ for $\left.30 \mathrm{sec}\right\}$ 45 Cycles

Stage 3 (Melt Curve Stage): $95^{\circ} \mathrm{C}$ for $15 \mathrm{sec}, 68^{\circ} \mathrm{C}$ for $60 \mathrm{sec}, 80^{\circ} \mathrm{C}$ for $15 \mathrm{sec}, 60^{\circ} \mathrm{C}$ for $15 \mathrm{sec}$

\section{QuantiTect SYBR Green:}

Stage 1 (Holding Stage): $95^{\circ} \mathrm{C}$ for $15 \mathrm{~min}$

Stage 2 (Cycling Stage): $95^{\circ} \mathrm{C}$ for $15 \mathrm{sec}, 60^{\circ} \mathrm{C}$ for $30 \mathrm{sec}$, $72^{\circ} \mathrm{C}$ for $\left.30 \mathrm{sec}\right\} 45$ Cycles
Stage 3 (Melt Curve Stage): $95^{\circ} \mathrm{C}$ for $15 \mathrm{sec}, 60^{\circ} \mathrm{C}$ for $60 \mathrm{sec}, 72^{\circ} \mathrm{C}$ for $30 \mathrm{sec}, 60^{\circ} \mathrm{C}$ for $15 \mathrm{sec}$

For each set of primers and probes described in Table 1 (QuantiFast Probe TaqMan), reaction mix consisting of $11 \mu \mathrm{L}$ of $2 \times$ QuantiFast Master Mix, $1 \mu \mathrm{L}$ of each10 uM $(0.4 \mu \mathrm{M})$ forward and reverse primer, and $1 \mu \mathrm{L}$ of $5 \mu \mathrm{M}$ probe $(0.2 \mu \mathrm{M})$ and $6 \mu \mathrm{L}$ of nuclease-free water was made to a total volume of $20 \mu \mathrm{L}$. From this, $5 \mu \mathrm{L}$ of the mix to $1 \mu \mathrm{L}$ template was used per reaction. For QuantiFast SYBR Green Master Mix or QuantiTect SYBR Green Master Mix, $10 \mu \mathrm{L}$ of $2 \times$ master mix, $1 \mu \mathrm{L}$ of each $10 \mu \mathrm{M}$ $(0.4 \mu \mathrm{M})$ forward and reverse primer and $8 \mu \mathrm{L}$ of nuclease-free water was made to a total volume of $20 \mu \mathrm{L}$. From this, $9 \mu \mathrm{L}$ of the mix to $1 \mu \mathrm{L}$ template was used per reaction as recommended by the manufacturer. Good laboratory techniques and quality controls were strictly adhered. Each assay was run with proper controls in place including no template control, endogenous control and positive controls.

\section{Summary of published assays analysed in this study}

1. Kamau et al [14], PLU3: Published LoD 0.0512 parasites $/ \mu \mathrm{L}, 1 \mu \mathrm{L}$ of DNA in $10 \mu \mathrm{L}$ total reaction volume in 1X QuantiTect Probe RT-PCR Master Mix (Qiagen). Efficiency not reported. Performed in ABI7500 platform.

2. Lee et al [10], MACH: Published LoD 0.1 parasites $/ \mu \mathrm{L}$, $5 \mu \mathrm{L}$ of DNA in $25 \mu \mathrm{L}$ total reaction volume in 1X TaqMan universal PCR master mix (Applied Biosystems, CA, USA). Efficiency not reported. Performed in iCycler (Bio-rad) platform.

3. Farrugia et al [13], CYTB: Published LoD 0.05 parasites $/ \mu \mathrm{L}, 5 \mu \mathrm{L}$ of DNA in $20 \mu \mathrm{L}$ total reaction volume in $1 \mathrm{X}$ Probe Master (Roche Molecular Biochemicals). Efficiency reported at 94.5\%. Performed in a LightCycler 480 instrument.

4. Padley et al [7], WHO: Published LoD 16.2 parasites $/ \mu \mathrm{L}$. The amount of DNA used and reaction total reaction volume not provided however, reports amplification reactions were performed using the Light-Cycler FastStart DNA Master Hybprobe kit (Roche Applied Science, Mannheim, Germany). Efficiency not reported. Performed in a LightCycler 2.0 instrument.

5. Perandin et al [12], FAL: Published LoD 0.7 parasites $/ \mu \mathrm{L}, 5 \mu \mathrm{L}$ of DNA in $50 \mu \mathrm{L}$ total reaction volume in $1 \mathrm{X}$ TaqMan universal PCR master mix (Applied Biosystems). Efficiency not reported. Performed in ABI 7700 platform.

6. Rougemont et al [11], PLASMO: LoD and Efficiency not published. $5 \mu \mathrm{L}$ of DNA in $25 \mu \mathrm{L}$ total reaction 
volume in $1 \mathrm{X}$ TaqMan universal PCR master mix (Applied Biosystems). Performed in ABI 7700 platform.

7. Hermsen et al [18],TURBO: Published LoD 0.02 parasites $/ \mu \mathrm{L}, 5 \mu \mathrm{L}$ of DNA in $25 \mu \mathrm{L}$ total reaction volume of $25 \mu \mathrm{L}$ of buffer containing $20 \mathrm{mM}$ Tris- $\mathrm{HCl}$, $100 \mathrm{mM} \mathrm{KCl}, 3 \mathrm{mM} \mathrm{MgCl} 2,0.02 \%$ gelatin, and $400 \mu \mathrm{M}$ deoxynucleoside triphosphates (Microsynth, Balgach, Switzerland). Efficiency not reported. Performed in a GeneAMP PCR system 9700 (Applied Biosystem).

\section{Analysis of samples obtained from a challenge study}

To further compare the assays described here, samples obtained from five subjects participating in an experimental $P$. falciparum infection study were analysed in triplicate using each of the seven assays being tested. Samples used for analysis were from positive control challenge subjects who did not receive any investigational product or licensed anti-malarial medication prior to challenge by the bite of infected mosquitoes. Samples were collected in EDTA blood and stored in $-20^{\circ} \mathrm{C}$ immediately until needed. DNA was extracted from the whole blood using EZ1 automated purification system (Qiagen, CA, USA) with the EZ1 DNA blood kit (Qiagen, CA, USA) following the manufacturer's recommendation. The study protocol for the clinical trial was reviewed and approved by the Human Use Review Committee of the Walter Reed Army Institute of Research (WRAIR) and by the Human Subjects Research and Review Board of the Surgeon General of the US Army at Fort Detrick, Maryland. The study was conducted in collaboration with US Agency for International Development (USAID), Infectious Disease Research Institute. Participants were provided written, informed consent before screening and enrolment and had to pass an assessment of understanding. The results of the clinical trial study will be reported elsewhere.

\section{Results}

\section{Comparison of PCR assays sensitivities}

The fluorescence emission of any molecule is dependent on environmental factors including the $\mathrm{pH}$ of the solution, salt concentration and much more. To obtain more accurate and representative performance of all the assays tested, assays were performed using TaqMan probe and SYBR Green formats. For the TaqMan probe format, the assays were performed in the background of QuantiFast Master Mix whereas in SYBR Green format, the assays were performed in the background of QuantiFast SYBR Green Master Mix and QuantiTect Sybr green Master Mix. All assays were performed in triplicate and the LoD was established as the highest $C_{q}$ value where the lowest parasite concentration was detected, expressed as parasites $/ \mathrm{mL}$. Only $\mathrm{C}_{\mathrm{q}}$ values 40 and below were considered and only two out of three assays were required to call the results a positive. It is important to note that at very low copy numbers, the normal distribution of the template in the sample is not expected. Instead, Poisson distribution is followed where only a certain percentage of copy number of the template is detected which is likely to vary each time resulting in a larger standard deviation (SD). For the TaqMan probe format, the PLU3 and MACH assays were the most sensitive with LoD of 313 parasites/mL whereas the CTYB and FAL were the least sensitive with LoD of 2,500 parasites/mL (Figure 1). The sensitivities of these assays were previously reported as follows: PLU3 at 50 parasites $/ \mathrm{mL}, \mathrm{MACH}$ at 100 parasites $/ \mathrm{mL}$, CTYB at 50 parasites $/ \mathrm{mL}$, WHO at 16,200 parasites $/ \mathrm{mL}, \mathrm{FAL}$ at 700 parasites $/ \mathrm{mL}$, and TURBO at 20 parasites $/ \mathrm{mL}$. The sensitivity of PLASMO assay was not reported.

\section{Comparison of the dynamic ranges and efficiencies of PCR assays}

Robust and precise qPCR assays are usually correlated with high PCR efficiency [12]. To evaluate PCR efficiency, each assay was performed in triplicates, with 5-log range in five-fold decrements of the template. A slope of $-3.3 \pm$ $10 \%$ reflects an efficiency of $100 \% \pm 10 \%$. PCR efficiency is highly dependent on the primers used. The presence of primer dimers may result in a lower PCR efficiency in a probe-based assay and may generate false positives in SYBR Green based assays. In TaqMan probe assay format, the PLU3 assay had the highest efficiency at 100.4\% whereas FAL had the lowest efficiency at 74.95\% (Table 2). Efficiency for CTYB assay was previously reported as 94.5\% [13] whereas in this study, efficiency of $88.2 \%$ was obtained. When the assays were run in SYBR Green format in the background of QuantiTect SYBR Green Master Mix, the PLU3 assay performed the best whereas

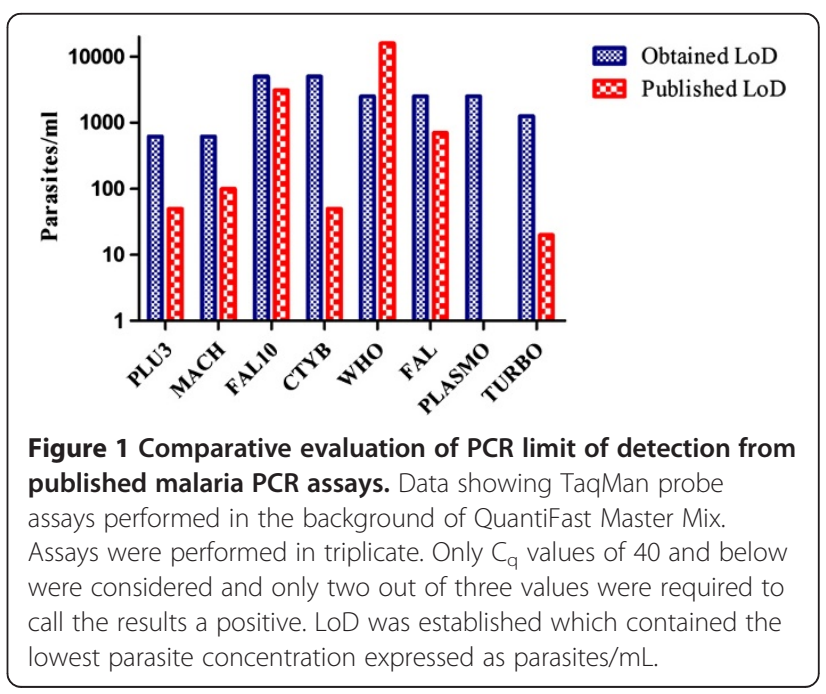


Table 2 TaqMan probe assay performance

\begin{tabular}{lllll}
\hline Assay & Slope & Y-Inter & $\mathbf{R}^{\mathbf{2}}$ & \% Eff \\
\hline PLU3 & -3.312 & 37.145 & 1 & 100.412 \\
MACH & -3.576 & 38.969 & 0.999 & 90.399 \\
CYTB & -3.643 & 37.54 & 0.999 & 88.154 \\
WHO & -3.386 & 38.74 & 0.998 & 97.394 \\
FAL & -4.116 & 43.601 & 0.998 & 74.954 \\
PLASMO & -3.643 & 36.686 & 0.998 & 88.135 \\
TURBO & -3.685 & 39.55 & 0.998 & 86.788 \\
\hline
\end{tabular}

the TURBO, WHO and CYTB assays completely failed (data not shown). Interestingly, in SYBR Green format, all assays performed better in QuantiFast SYBR Green Master Mix than they did in QuantiTect SYBR Green Master Mix. The PLU3 assay performed with the highest efficiency in SYBR Green QuantiFast Master Mix at 95.4\% whereas FAL had the lowest efficiency at 40.1\% (Table 3).

\section{Comparison of $\mathrm{R}^{2}$ values and precision of PCR assays}

Correlation co-efficient $R^{2}$ value is a statistical term that indicates how predictive one value is of another. It is also a critical value for evaluating PCR efficiency. The value of $\mathrm{Y}\left(\mathrm{C}_{\mathrm{q}}\right)$ can be used to accurately predict the value of $X$ when the $R^{2}$ is 1 . An $R^{2}$ value of 0.99 provides good confidence in correlating two values. Using the QuantiFast probe TaqMan assay format, the $\mathrm{R}^{2}$ values of all the assays were $>0.99$ (Table 2). There are numerous causes for variations in qPCR results, including temperature differences (temperature affects annealing and/or denaturation), pipetting errors, stochastic variation, etc. SD is a measure of precision that typically varies in qPCR with concentration and with decreasing copy number. To compare the precision of the assays tested, the $\mathrm{SD}$ of $\mathrm{C}_{\mathrm{q}}$ values in two different dilutions containing 4,699 parasites/ $\mu \mathrm{L}$ [high] and 4.7 parasites/ $\mu \mathrm{L}$ [low] of the TaqMan assays were evaluated. In addition, SD at LoD was determined. The PLU3 assay had the smallest SD at all the parasite concentrations tested, which indicated superior performance whereas FAL had the poorest performance (Table 4).

Table 3 SYBR Green QuantiFast assay performance

\begin{tabular}{lllll}
\hline Assay & Slope & Y-Inter & $\mathbf{R}^{\mathbf{2}}$ & \% Eff \\
\hline PLU3 & -3.438 & 35.132 & 0.999 & 95.389 \\
MACH & -3.627 & 37.421 & 0.998 & 88.683 \\
CYTB & -3.605 & 36.122 & 0.997 & 89.419 \\
WHO & -3.585 & 38.815 & 0.999 & 90.095 \\
FAL & -6.834 & 57.967 & 0.998 & 40.067 \\
PLASMO & -4.07 & 40.183 & 0.998 & 76.088 \\
TURBO & -4.092 & 42.658 & 0.998 & 75.551 \\
\hline
\end{tabular}

Table 4 SD as a measure of precision of assays tested

\begin{tabular}{|c|c|c|c|}
\hline \multirow[t]{2}{*}{ Assay } & \multirow{2}{*}{$\frac{\mathrm{SD}}{\text { Lowest Cq values }}$} & \multirow{2}{*}{$\frac{\mathrm{SD}}{\text { Highest } \mathrm{Cq} \text { values }}$} & \multirow{2}{*}{$\frac{\mathrm{SD}}{\text { LoD Cq values }}$} \\
\hline & & & \\
\hline PLU3 & 0.044 & 0.249 & 0.000 \\
\hline $\mathrm{MACH}$ & 0.062 & 0.338 & 0.142 \\
\hline CYTB & 0.113 & 0.454 & 1.082 \\
\hline WHO & 0.134 & 0.561 & 0.943 \\
\hline FAL & 0.294 & 0.996 & 1.113 \\
\hline PLASMO & 0.069 & 0.561 & 0.663 \\
\hline TURBO & 0.096 & 0.509 & 0.200 \\
\hline
\end{tabular}

$\mathrm{SD}$ is a measure of precision of each qPCR assay at different parasite concentrations. Lower values represent higher precision.

\section{Analysis of samples from clinical trial study}

The seven assays being tested were further evaluated using clinical samples from five unvaccinated positive control subjects as described in methods section. Samples were analysed in triplicate using the TaqMan probe assay format, performed in the background of QuantiFast Probe Master Mix. Microscopy was used as the reference method for the detection of parasites and initiation of treatment whereas qPCR was used as an exploratory method. Samples were considered microscopy positive when a minimum of two unambiguous parasites were visualized and clearly identified after examining about $0.55 \mu \mathrm{L}$ of blood in a Giemsa-stained thick smear. Table 5 summarizes the results for all assays evaluated and illustrates the day of detection for each clinical sample by each qPCR assay (first $\mathrm{C}_{\mathrm{q}}$ value obtained) as compared to microscopy. The performance of each $\mathrm{qPCR}$ assay was assessed by comparing the number of days each assay detected parasites before microscopy. The PLU3 assay was the most sensitive, detecting parasites on average three days before microscopy, whereas the FAL assay was the least sensitive, detecting parasite only 0.6 days before microscopy.

\section{Discussion}

A variety of diagnostic methods exist that are used for identification and speciation of Plasmodium parasites. Microscopic detection of malaria parasites on Giemsastained blood smears is still considered the gold standard method for malaria diagnosis, clinical trials efficacy evaluation and epidemiological surveys. However, microscopy has numerous limitations such as low sensitivity, difficulties in quality control and standardization, operator dependence, poor specificity, and the need for continued training and evaluation [4,6,23,24]. Identification of parasites specific antigens, antibodies and nucleic acid sequences form the basis of established and novel diagnostic modalities. Nucleic acid amplification techniquebased assays, such as qPCR are becoming increasingly employed in the diagnosis of malaria $[12,15,25,26]$. Studies 
Table 5 Clinical trial study

\begin{tabular}{|c|c|c|c|c|c|c|c|c|c|c|}
\hline Assay & ID & D0 & D1 & D2 & D3 & D4 & D5 & D6 & DBM & Avg DBM \\
\hline \multirow[t]{5}{*}{ Micro } & 1 & & & & $P$ & & & & & \\
\hline & 2 & & & & $P$ & & & & & \\
\hline & 3 & & & & & $P$ & & & & \\
\hline & 4 & & & & & & $P$ & & & \\
\hline & 5 & & & & & & $P$ & & & \\
\hline \multirow[t]{5}{*}{ PLU3 } & 1 & & $P$ & & & & & & 2 & 3 \\
\hline & 2 & & $P$ & & & & & & 2 & \\
\hline & 3 & & $P$ & & & & & & 3 & \\
\hline & 4 & & $P$ & & & & & & 4 & \\
\hline & 5 & & $P$ & & & & & & 4 & \\
\hline \multirow[t]{5}{*}{$\mathrm{MACH}$} & 1 & & & $P$ & & & & & 1 & 1.8 \\
\hline & 2 & & $P$ & & & & & & 2 & \\
\hline & 3 & & & $P$ & & & & & 2 & \\
\hline & 4 & & & & $P$ & & & & 2 & \\
\hline & 5 & & & & $P$ & & & & 2 & \\
\hline \multirow[t]{5}{*}{ CYTB } & 1 & & & $P$ & & & & & 1 & 1.6 \\
\hline & 2 & & & $P$ & & & & & 1 & \\
\hline & 3 & & & $P$ & & & & & 2 & \\
\hline & 4 & & & & $P$ & & & & 2 & \\
\hline & 5 & & & & $P$ & & & & 2 & \\
\hline \multirow[t]{5}{*}{ WHO } & 1 & & $P$ & & & & & & 2 & 2 \\
\hline & 2 & & & $P$ & & & & & 1 & \\
\hline & 3 & & $P$ & & & & & & 2 & \\
\hline & 4 & & & & $P$ & & & & 2 & \\
\hline & 5 & & & $P$ & & & & & 3 & \\
\hline \multirow[t]{5}{*}{ FAL } & 1 & & & & $P$ & & & & 0 & 0.6 \\
\hline & 2 & & & & $P$ & & & & 0 & \\
\hline & 3 & & & & $P$ & & & & 1 & \\
\hline & 4 & & & & & $P$ & & & 1 & \\
\hline & 5 & & & & & $P$ & & & 1 & \\
\hline \multirow[t]{5}{*}{ PLASMO } & 1 & & & $P$ & & & & & 1 & 1.2 \\
\hline & 2 & & & $P$ & & & & & 1 & \\
\hline & 3 & & & & $P$ & & & & 1 & \\
\hline & 4 & & & & & $P$ & & & 1 & \\
\hline & 5 & & & & $P$ & & & & 2 & \\
\hline
\end{tabular}

Table 5 Clinical trial study (Continued)

\begin{tabular}{l}
\hline TURBO \\
5 \\
Table showing the number of Days (D) the samples became positive (P) by \\
either microscopy (Micro) or qPCR assays. D1 is the day when the first qPCR \\
assay was positive. The designation of days is arbitrary for comparison of qPCR \\
assays to microscopy and does not reflect the actual day of qPCR positivity \\
post infection challenge. DBM is the number of days samples were qPCR \\
positive before they became microscopy positive. The actual $C_{\mathrm{q}}$ values are not \\
shown. The last column shows the average number of days (Avg DBM) the \\
samples were qPCR positive (for each assay) before they were microscopy \\
positive for all the five volunteers.
\end{tabular}

have clearly demonstrated that qPCR methods have improved sensitivity and species identification compared to microscopy $[7,14]$. There is a wide variation in the sensitivity of the numerous PCR methods that have been developed for the laboratory diagnosis and clinical management of malaria [21]. These differences may be attributed to the intrinsic variability in assay sensitivity or a consequence of calibration using different reference reagents, which are poorly standardized [12]. In this study, the WHO International Standard for P. falciparum DNA was used as a calibration reference reagent to compare the sensitivity of a few published qPCR assays for detection of malaria. The MIQE guidelines were followed during experiment set-up and execution to ensure relevance, accuracy, correct interpretation, and repeatability of the assays that were being analysed and compared. The PLU3 assay performed extremely well and was consistent compared to the other assays regardless of the assay format (either TaqMan probe or SYBR green) or background (QuantiFast probe Master Mix, QuantiFast SYBR green Master Mix or QuantiTect SYBR green Master Mix). The MACH assay performed equally well. There is probably other qPCR malaria assays not included, published or not, that might perform as well or better. With exception of the WHO assay, all the qPCR assays tested had higher LoD (less sensitive) compared to the published LoD. This difference can be explained by many factors including calibration using different reference reagents and data interpretation.

Although sensitivity is important, other factors should be considered when designing or selecting qPCR assay to adopt or use in a project. Plasmodium falciparum growth is usually characterized by an exponential increase in the number of parasite-infected erythrocytes, followed by marked oscillations in this number with a periodicity of 48 hours, which are eventually dampened [27]. This reproductive pattern leads to variation in parasite densities in peripheral blood. As such, the small differences in assay sensitivity demonstrated here might not be 
clinically relevant. In addition, different settings may require qPCR assays with different sensitivities. The severity of malaria disease does not just depend on the parasite density, but depends on many factors such the immune status of the patient or subject in addition to other factors. For non-immune patients or subjects, smaller amounts (or changes thereof) of parasites may cause malaria disease much more compared to immune patients or subjects, therefore requiring qPCR with higher sensitivity. However, regardless of the setting, qPCR assays must be consistent and reproducible in addition to being highly sensitive; these qualities can be established if qPCR assays are designed and tested following the MIQE guidelines.

Some of the key characteristics that are critical in qPCR experiments and must be considered conceptually include analytical sensitivity, analytical specificity, accuracy, repeatability, and reproducibility. It is important that published assays are reproducible within reason or range if performed following the same chemistries and platform as those described in respective publication. Even with change in chemistries and platform, the performance of the assay should remain relatively consistent. Such characteristic (consistency) in performance can only be evaluated if the assay calibration is done using a standard reference reagent, such as the WHO International Standard for P. falciparum DNA. The quality and integrity of the nucleic acids being analysed is just as critical in performance of the assay. Therefore, use of standard controls, such as the WHO International Standard for P. falciparum DNA, in every $\mathrm{qPCR}$ assay as positive control is critical in ensuring that the qPCR assays perform consistently. To ensure consistency and minimize variability, all the assays tested here were performed on the same 96-well plate when possible and the same DNA dilutions were used in all the assays.

Data analysis is also important in ensuring impartial results. In most qPCR platforms, the post-run data are analysed using the software supplied with the instrument. Proper baseline and threshold setting is required in getting a final quantifiable $\mathrm{C}_{\mathrm{q}}$ value for each run. Such settings can be done manually or automatically in open qPCR platforms. Manually changing the threshold settings can drastically change the $\mathrm{C}_{\mathrm{q}}$ values. It is likely that such practices account for dramatic differences seen in obtained and published LoD. To ensure that there was no bias towards data interpretation and analysis in this study, automatic manufacturer's settings were used to establish threshold and for data interpretation.

The performance of the assays in analysis of the clinical trial samples corresponded well with the established base-line performance of the assays. The PLU3 assay which had been established to be the most sensitive, detected parasites on average three days before microscopy followed by the MACH assay. The FAL assay was the least sensitive; had the lowest performance in the analysis of clinical samples and had the worst LoD. These data show that proper evaluation of molecular assays following proper guidelines results in an assay with reliable, reproducible and superior performance.

\section{Conclusion}

For the first time, the performances of several PCR assays developed by different laboratories for detection of malaria have been compared side by side. To ensure unbiased and objective comparison of the performance of the qPCR assays, data was generated with clearly defined experimental design, procedures and instrumentation for DNA extraction, as well as the analysis. In addition, $\mathrm{qPCR}$ assays tested were validated using MIQE guidelines and commercially available reference DNA sample. When designing and evaluating qPCR assays, the focus should be the chemistries regardless of the background and platform used. Data presented here show that qPCR assays with superior performance characteristics such as high efficiency and precision perform better in analysis of clinical samples than those with poor performance characteristics. With exception of the WHO assay, qPCR assays analysed did not perform with similar sensitivities as previously shown. It is recommended that the work described here, either using the same and/or additional malaria qPCR assays be performed by other group(s) as well. It is absolutely important that such testing and comparison of the performances of qPCR assays use well defined guidelines such as MIQE and same reference reagent(s) such as the WHO International Standard for P. falciparum DNA. Reference reagent(s) can also be prepared internally but the same reagent(s) must be shared and used by all the participating laboratories in such a study.

The purpose of this study was not to endorse or discredit any of the published assays. It is likely most established laboratories will continue using their laboratory developed qPCR assays for detection of malaria. However, it is critical to reach a consensus or standardized method of performing $\mathrm{qPCR}$ assay to facilitate the evaluation and/or comparison of the qPCR assays reported by different authors and laboratories. This will be especially important for a cross-study and/or cross-platform comparison.

\section{Competing interests}

The authors declare that they have no competing interests.

\section{Authors' contributions}

EK, SA and CFO conceived and designed the experiments. SA, KCF and EK performed the experiments. SA and EK analysed the data. JC, JK and CFO contributed reagents/materials/analysis tools. EK and SA wrote the Manuscript: EK, SA. KCF, JK, JC, and CFO reviewed the manuscript. All authors read and approved the final manuscript. 


\section{Acknowledgments}

We would like to acknowledge all the authors who previously published their studies and as such, we were able to compare their work. This is important for science and our goal is to initiate discussion and stimulate interest in harmonising malaria PCR. We would also like to thank the volunteers who participated in the clinical trial. This material has been reviewed by the Walter Reed Army Institute of Research. There is no objection to its presentation and/or publication. The opinions or assertions contained herein are the private views of the author, and are not to be construed as official, or as reflecting true views of the Department of the Army, the Department of Defense or the U.S. Government.

Received: 1 June 2013 Accepted: 2 August 2013

Published: 8 August 2013

\section{References}

1. Kain KC, Harrington MA, Tennyson S, Keystone JS: Imported malaria: prospective analysis of problems in diagnosis and management. Clin Infect Dis 1998, 27:142-149.

2. Hawkes M, Kain KC: Advances in malaria diagnosis. Expert Rev Anti Infect Ther 2007, 5:485-495.

3. Coleman RE, Sattabongkot J, Promstaporm S, Maneechai N, Tippayachai B, Kengluecha A, Rachapaew N, Zollner G, Miller RS, Vaughan JA, Thimasarn K, Khuntirat B: Comparison of PCR and microscopy for the detection of asymptomatic malaria in a Plasmodium falciparum/vivax endemic area in Thailand. Malar J 2006, 5:121.

4. Payne D: Use and limitations of light microscopy for diagnosing malaria at the primary health care level. Bull World Health Organ 1988, 66:621-626.

5. Ohrt C, Purnomo, Sutamihardja MA, Tang D, Kain KC: Impact of microscopy error on estimates of protective efficacy in malaria prevention trials. I Infect Dis 2002, 186:540-546.

6. Ohrt C, Obare P, Nanakorn A, Adhiambo C, Awuondo K, O'Meara WP, Remich S, Martin K, Cook E, Chretien JP, Lucas C, Osoga J, McEvoy P, Owaga ML, Odera JS, Ogutu B: Establishing a malaria diagnostics centre of excellence in Kisumu, Kenya. Malar J 2007, 6:79.

7. Perandin F, Manca N, Calderaro A, Piccolo G, Galati L, Ricci L, Medici MC, Arcangeletti MC, Snounou G, Dettori G, Chezzi C: Development of a real-time PCR assay for detection of Plasmodium falciparum, Plasmodium vivax, and Plasmodium ovale for routine clinical diagnosis. J Clin Microbiol 2004, 42:1214-1219.

8. Veron VS, Simon S, Carme B: Multiplex real-time PCR detection of $P$. falciparum, $P$. vivax and $P$. malariae in human blood samples. Exp Parasitol 2009, 121:346-351.

9. Hermsen CC, Telgt DS, Linders EH, van de Locht LA, Eling WM, Mensink EJ, Sauerwein RW: Detection of Plasmodium falciparum malaria parasites in vivo by real-time quantitative PCR. Mol Biochem Parasitol 2001, 118:247-251.

10. Lee MA, Tan CH, Aw LT, Tang CS, Singh M, Lee SH, Chia HP, Yap EP: Real-time fluorescence-based PCR for detection of malaria parasites. J Clin Microbiol 2002, 40:4343-4345.

11. Rougemont M, Van Saanen M, Sahli R, Hinrikson HP, Bille J, Jaton K: Detection of four Plasmodium species in blood from humans by $18 \mathrm{~S}$ rRNA gene subunit-based and species-specific real-time PCR assays. J Clin Microbiol 2004, 42:5636-5643.

12. Padley DJ, Heath AB, Sutherland C, Chiodini PL, Baylis SA, Collaborative Study Group: Establishment of the 1st World Health Organization International Standard for Plasmodium falciparum DNA for nucleic acid amplification technique (NAT)-based assays. Malar J 2008, 7:139.

13. Farrugia C, Cabaret O, Botterel F, Bories C, Foulet F, Costa JM, Bretagne S: Cytochrome $b$ gene quantitative PCR for diagnosing Plasmodium falciparum infection in travelers. J Clin Microbiol 2011, 49:2191-2195.

14. Kamau E, Tolbert LS, Kortepeter L, Pratt M, Nyakoe N, Muringo L, Ogutu B, Waitumbi JN, Ockenhouse CF: Development of a highly sensitive genusspecific quantitative reverse transcriptase real-time PCR assay for detection and quantification of Plasmodium by amplifying RNA and DNA of the 18S rRNA genes. J Clin Microbiol 2011, 49:2946-2953.

15. Sauerwein RW, Roestenberg M, Moorthy VS: Experimental human challenge infections can accelerate clinical malaria vaccine development. Nat Rev Immunol 2011, 11:57-64.

16. Moorthy VS, Diggs C, Ferro S, Good MF, Herrera S, Hill AV, Imoukhuede EB, Kumar S, Loucq C, Marsh K, Ockenhouse CF, Richie TL, Sauerwein RW:
Report of a consultation on the optimization of clinical challenge trials for evaluation of candidate blood stage malaria vaccines, 18-19 March 2009, Bethesda, MD, USA. Vaccine 2009, 27:5719-5725.

17. Okell LC, Ghani AC, Lyons E, Drakeley CJ: Submicroscopic infection in Plasmodium falciparum-endemic populations: a systematic review and meta-analysis. J Infect Dis 2009, 200:1509-1517.

18. Hermsen CC, De Vlas SJ, Van Gemert GJA, Telgt DS, Verhage DF, Sauerwein RW: Testing vaccines in human experimental malaria; statistical analysis of parasitemia measured by a quantitative real-time polymerase chain reaction. Am J Trop Med Hyg 2004, 71:196-201.

19. Bejon P, Andrews L, Andersen RF, Dunachie S, Webster D, Walther M, Gilbert SC, Peto T, Hill AV: Calculation of liver-to-blood inocula, parasite growth rates, and preerythrocytic vaccine efficacy, from serial quantitative polymerase chain reaction studies of volunteers challenged with malaria sporozoites. J Infect Dis 2005, 191:619-626.

20. Snounou G, Pinheiro L, Goncalves A, Fonseca L, Dias F, Brown KN, do Rosario $V$ : The importance of sensitive detection of malaria parasites in the human and insect hosts in epidemiological studies as shown by the analysis of field samples from Guinea-Bissau. Trans $R$ Soc Trop Med Hyg 1993, 87:649-653.

21. Berry A, Benoit-Vical F, Fabre R, Cassaing S, Magnaval JF: PCR-based methods to the diagnosis of imported malaria. Parasite 2008, 15:484-488.

22. Bustin SA, Benes V, Garson JA, Hellemans J, Huggett J, Kubista M, Mueller R, Nolan T, Pfaffl MW, Shipley GL, Vandesompele J, Wittwer CT: The MIQE guidelines: minimum information for publication of quantitative real-time PCR experiments. Clin Chem 2009, 55:611-622.

23. O'Meara WP, Barcus M, Wongsrichanalai C, Muth S, Maguire JD, Jordan RG, Prescott WR, McKenzie FE: Reader technique as a source of variability in determining malaria parasite density by microscopy. Malar J 2006, 5:118.

24. Padley D, Moody AH, Chiodini PL, Saldanha J: Use of a rapid, single-round, multiplex PCR to detect malarial parasites and identify the species present. Ann Trop Med Parasitol 2003, 97:131-137.

25. Johnston SP, Pieniazek NJ, Xayavong MV, Slemenda SB, Wilkins PP, da Silva $\mathrm{AJ}$ : PCR as a confirmatory technique for laboratory diagnosis of malaria. J Clin Microbiol 2006, 44:1087-1089.

26. Perandin F, Manca N, Piccolo G, Calderaro A, Galati L, Ricci L, Medici MC, Arcangeletti C, Dettori G, Chezzi C: Identification of Plasmodium falciparum, $P$. vivax, P. ovale, and P. malariae and detection of mixed infection in patients with imported malaria in Italy. New Microbiol 2003, 26:91-100.

27. Hoshen MB, Heinrich R, Stein WD, Ginsburg H: Mathematical modelling of the within-host dynamics of Plasmodium falciparum. Parasitology 2000, 121:227-235.

\section{doi:10.1186/1475-2875-12-277}

Cite this article as: Alemayehu et al:: Comparative evaluation of published real-time PCR assays for the detection of malaria following MIQE guidelines. Malaria Journal 2013 12:277.

\section{Submit your next manuscript to BioMed Central and take full advantage of:}

- Convenient online submission

- Thorough peer review

- No space constraints or color figure charges

- Immediate publication on acceptance

- Inclusion in PubMed, CAS, Scopus and Google Scholar

- Research which is freely available for redistribution 